\title{
Е.Е. Дымонт
}

Новосибирский государственный педагогический университет

\section{Основные типы текстовых функций перфекта в художественном тексте}

Аннотация: В статье рассматриваются особенности функционирования словоформ с перфектным значением в художественном тексте. Выделяются основные типы текстовых функций перфекта на основании комплекса признаков: разновидности перфектного значения, позиции глагола в тексте, лексических и грамматических характеристик глагола.

This article describes types of text functions of verb forms with perfect meaning in the narrative. Are allocated the main types of text functions of a perfect on the basis of a complex of signs: versions of perfect meaning, a verb position in the text, lexical and grammatical characteristics of a verb.

Ключевые слова: перфект, перфектное значение, текстовые категории.

Perfect, perfect meaning, text categories.

УДК: $81 ` 367.7$.

Контактная информация: Новосибирск, Вилюйская, 28. НГПУ, кафедра современного русского языка. E-mail: katiad@mail.ru.

Перфект издавна изучается в лингвистике главным образом с точки зрения семантики и способов выражения (в работах К.А. Тимофеева [Тимофеев, 1941], А.В. Бондарко [Бондарко, 1998], Ю.С. Маслова [Маслов, 2004], Е.Н. Прокопович [Прокопович, 1982], В.Б. Кашкина [Кашкин, 1991] и других), но его текстовые функции остались недостаточно исследованными. Способность перфекта к выполнению текстовых функций является следствием особой лексико-грамматической природы перфекта, его двуплановости [Маслов, 2004; Пупынин, 1996]: словоформы с перфектным значением выражают связь более раннего временного плана и более позднего, действия и состояния. На этих семантических особенностях базируется сложный комплекс текстовых функций: продвижения повествования и его задержки, ретроспективно-проспективных связей, а также субъективного отражения действительности, реализующегося благодаря дейктической ориентированности перфектного значения, важности для него точек отсчета.

В ряде работ отмечаются функции перфекта в художественном повествовании, диалоге и поэтическом тексте, говорится о том, что формы с перфектным значением благодаря своей дейктической ориентированности гораздо больше связаны с диалогическим режимом, чем с повествовательным [Маслов, 2004; Князев, 1976; Золотова, 1981], поскольку именно в диалоге особо важны точки отсчета. Однако не менее важны его текстовые функции в повествовательном режиме, так как в нем словоформы с перфектным значением выполняют целый комплекс текстообразующих функций.

(C) Е.Е. Дымонт 
Материалом исследования послужила художественная проза конца XX - начала XXI века: рассказы и повести В. Пелевина, Л. Улицкой, Т. Толстой и др.

Нами было выделено три типа текстовых функций, реализующихся глагольными формами в перфектном значении: композиционные функции, сюжетнособытийные функции и функции авторского комментирования.

Для каждого типа функций важны различные условия реализации перфектного значения: особенности лексического значения глагола, грамматические характеристики, показатели контекста, актуализирующие перфектное значение, позиция глагольной словоформы в высказывании и сложном синтаксическом целом. Разделение функций произведено нами условно, в исследовательских целях, так как в реальном тексте один и тот же глагол может выполнять несколько функций одновременно.

Под композиционными (связующими) функциями понимается способность словоформы с перфектным значением осуществлять связь между сложными синтаксическими целыми (ССЦ) и между высказываниями внутри ССЦ. Эта общая функция реализуется в трех разновидностях: проспекция, ретроспекция, проспекция-ретроспекция.

Если глагол осуществляет функцию проспекции, то он обычно находится в начале ССЦ и называет событие как завершенное действие, результат которого уже известен в момент речи, чем «стимулирует» последующий текст к раскрытию его конкретного содержания. Глаголы в перфектном значении выполняют проспективную функцию благодаря сильной валентности (глагол управляет словоформой с делиберативным значением). Чаще всего в этой роли выступают глаголы совершенного вида следующих лексико-семантических групп: речи, восприятия, ментальной деятельности (рассказал, объяснил, узнал, понял, увидел и т.д.), например, глагол увидела в следующем контексте: (1) Ирина отчетливо вдруг увидела, как молодая Симка с синей чашкой в руках сидит перед жесткой белизной их семейного стола <... А она, Ирочка, сидит под золоченым круглым столиком в углу комнаты и смотрит на странную гостью (Л. Улицкая. Бронька).

Проспективную функцию можно считать текстообразующей, так как употребление такого глагола предопределяет развитие микротемы в ССЦ за счет реализации синтаксической и лексико-семантической валентности словоформы.

Позиция словоформы оказывается важнее других признаков, потому что в подобной функции иногда могут употребляться и глаголы других лексикосемантических групп, даже не обладающие изъяснительной валентностью: (2) Бог знает из какой глубины выплыл вдруг образ Маргаритиного одноклассника Миши, жестоко в нее влюбленного с первого класса и обивавщего ее порог еще в десятом, когда Маргарита была уже невестой Серго. Этому женоподобному тонкорукому скрипачу Серго не придавал тогда никакого значения... (Л. Улицкая. Чужие дети).

В данном случае употреблен глагол движения в метафорическом значении «предстал перед глазами, возник», в котором также содержится сема восприятия, что способствует реализации проспективной функции.

Если словоформа с перфектным значением выполняет функцию ретроспекции, то она обычно находится в конце ССЦ и ее главная функция - отсылка к предшествующему контексту, связь данного высказывания с предыдущими. При помощи такого глагола может выражаться обобщение или вывод говорящего о событии. В этой функции достаточно часто выступает особая разновидность перфекта (результативно-фактический перфект), представляющая результат действия в виде факта (независимо от конкретного времени совершения действия). Эта разновидность перфектного значения реализуется у глаголов совершенного (произошло, случилось) и несовершенного вида (видел, сльшал): (3) Стояла все та же осень. Но Ирина Михайловна несла в себе какое-то глубокое и горькое изменение и никак не могла понять, цто же произошло (Л. Улицкая. Бронька); (4) Оба 
бандита уже сидели на заднем сиденье джипа с охраной, а старик в коричневом плаще горячо оправдывался перед равнодушными телохранителями. Татарский уже видел этого старика - это был преподаватель философии из Литинституmа (В. Пелевин. Generation Р).

И в функции проспекции, и в функции ретроспекции регулярно выступают глаголы восприятия, но если в первом случае употребляются преимущественно глаголы совершенного вида (акционально-перфектное значение), то во втором несовершенного (результативно-фактическое перфектное значение). Таким образом, глаголы одной и той же лексико-семантической группы, выполняющие разные композиционные функции, отличаются не только позицией в ССЦ, но и грамматическими характеристиками.

Важную роль в реализации ретроспективной связи играют дейктические актуализаторы перфектного значения: указательные местоименные слова, включая наречия (этот, такой, так, поэтому...). Ретроспективность местоимений связана с их заместительной функцией, с наличием в предшествующем тексте антецедента. Употребление местоимений в окружении глагола с перфектным значением способствует реализации ретроспекции даже в тех случаях, когда глагол находится в начале ССЦ. В таком случае можно говорить о проспективноретроспективной связи: (5) Мой отеи, неисправимый материалист, с серьезнылм видом обходит стол, постукивая ножом по каждому бокалу с шампанским. ... Я знаю, почему: он мне рассказал. Праздновали новый, 1941 год... (Т. Толстая. Ночь Феникса). Глагол рассказал, с одной стороны, указывает на причину ситуации, представленной в предыдущем высказывании (отец... обходит стол, постукивая ножом по бокалу...). С другой стороны, его валентность раскрывается в следующем высказывании (рассказал, как праздновали...). Аналогичную функцию выполняет перфект понял в следующем примере: (6) Обойдя статую кругом $<\ldots>$, Татарский окончательно понял, что в душу заползла депрессия. Ее можно было убрать двумя методами (В. Пелевин). Таким образом, один и тот же глагол в перфектном значении может реализовать и ретроспективную связь благодаря причинно-следственным отношениям, устанавливающимся между высказываниями, и проспективную связь благодаря синтаксической валентности глагола, требующего раскрытия содержания ментального действия.

Итак, способость к выполнению ретроспективной и проспективной функций вытекает из особого значении перфекта, а текстовые актуализаторы помогают глагольной словоформе их реализовать.

Другим типом функций в художественном тексте являются сюжетнособытийные, под которыми понимается роль глагольной формы в событийном ряде повествования, в хронологической последовательности событий. Мы будем вслед за Ю.С. Масловым [Маслов, 2004] различать следующие их разновидности: прогресс (наступление новой ситуации, следующего этапа развития сюжета, продвижение повествования вперед), регресс (возврат фокуса внимания говорящего к более раннему событию), остановка повествования.

Продвижение повествования, как правило, связано с акциональным (результативным) перфектом, а остановка - со статальным (качественным). Чаще всего в функции продвижения повествования употребляются глаголы воздействия на объект, движения: (7)Черная пасть духовки поглотила сырое, бледное нечто, чтобы через положенный срок исторгнуть великолепный, желанный дар - пульсирующий счастьем сладкий пирог (поглотила - глагол физического воздействия на объект в акционально-перфектном значении); (8) Ее украл краснылй дракон, полетал с ней по белу свету и завез сюда, в дачный поселок. И теперь она живет в самом дальнем доме (Т. Толстая.).

Поскольку такой перфект по своим свойствам близок к глагольным формам с аористическим значением, то в окружающем словоформу контексте очень часто присутствуют актуализаторы перфектного значения, подчеркивающие результа- 
тивность и связь действия с более поздним временным планом (в данном случае это футурально направленная целевая придаточная часть чтобы исторгнуть..., в других могут быть также формы настоящего или будущего времени). В таком употреблении перфектные глаголы связаны с понятием возникновения новой ситуации (согласно мнению А.В. Бондарко [Бондарко, 1998], акциональный перфект связан с возникновением новой ситуации, статальный - нет).

В тех случаях, когда в тексте у глагола реализуется функция регресса, можно говорить о плюсквамперфектном значении как особой разновидности перфектного: (9) Отеи посмотрел-посмотрел и вдруг понял, что все отменяется. Что ему еще можно жить. Что никто никогда не умрет. А те шестеро <...> все пережсили войну, все выюжил... (Т. Толстая. Ночь Феникса); (10) И вдруг в душе ее возникла необъяснимая тень недовольства своей жизнью, неловкости за свое полное и заслуженное благополучие. "Да нет, глупости, - промелькнуло в мыслях, - чего же плохого в том, что родители дали мне хорошее образование и обеспечили всем необходимым для жизни...». И она, вернувшись глазами к фотографиям, сменила тему (Л. Улицкая. Бронька). Действия пережили, выжили (фрагмент 9) и дали, обеспечили (фрагмент 10) относятся к более раннему временному плану, чем ситуация предшествующего высказывания.

Функцию остановки повествования выполняет прежде всего качественный перфект, который чаще всего выражен страдательным причастием со связкой (смята, намечен): (11) Светает. На столе развал. Скатерть смята, свечи погасли. Отеи, старенький человек, видевий феникса, заснул в кресле. Выйдем же на цыпочках, тихо, в новое утро (Т. Толстая. Ночь Феникса); (12) Легкая карельская ночь. Нет ни тьмы, ни алой зари - вечный бельй вечер. Утихли все краски, в светлой вышине облачным мазком намечен крупинчатый месяи (Т. Толстая). В качестве актуализаторов перфектного значения употреблены различные языковые средства выражения статичности: номинативные конструкции и предикаты с нулевой связкой (на столе развал, легкая карельская ночь), презенс глаголов состояния (светает), другие глаголы состояния в перфектном значении (погасли, заснул).

Под функцией авторского комментирования понимается выражение позиции говорящего по отношению к событию, сопоставляющего разные точки зрения на него, выражающего свои умозаключения, оценивающего достоверность события.

Благодаря уже отмеченной двуплановости перфектного значения глагольные формы могут употребляться для выражения сопоставления либо точек зрения разных говорящих, либо сопоставления положения дел в разные моменты времени: (13) Выяснилось, что он совершенно ничего не знает про мир, который успел возникнуть вокруг за несколько последних лет. Все вокруг как-то сразу постарело и опустилось... (Т. Толстая. Река Оккервиль).

Сопоставление двух временных ситуаций происходит в сознании одного и того же субъекта. К типичным способам выражения такого сопоставления можно отнести конструкцию успел + инфинитив (успел возникнуть) и глаголы совершенного вида инхоативного способа действия (глаголы перехода в новое качество - «стать каким-либо»: постарело, опустилось). С помощью глагола в перфектном значении выражается противопоставление двух ситуаций: (14) Зажигаются дуговые фонари - вот был мертв и молчал, а гляди - уже болезненной технической звездой зажглась и раздувается розоватая марганциовая точка, и разливается, и растет, и светлеет (Т. Толстая. Круг).

Словоформы с перфектным значением могут выполнять также функцию обобщения: номинация конкретного действия обозначает целый класс подобных действий, наглядно-примерное употребление совершенного вида, по А.В. Бондарко [Бондарко, 1998]. Такую функцию выполняют глаголы схватил, прошел, удалась в следующих примерах: (15) Нужно обязательно, чтобы челове- 
ческую душу схватил иногда заморозок, чтобы она сжалась на миг от чувства неповторимости чего-то очень важного и нужного (В. Лидин); (16) Часто бывает - проезжаешь в белом «мерседесе» мимо автобусной остановки, видишь людей, Бог знает сколько времени остервенело ждущих своего автобуса, и вдруг замечаешь, что кто-то из них мутно и вроде бы даже с завистью глядит на тебя... <..> И волна горячей дрожи проходит по телу; гордо отворачиваешь лицо от стоящих на остановке и решаешь в своем сердче, что не зря прошел через известно что и жизнь удалась (В. Пелевин. Generation P).

Выражение обобщения может сочетаться в перфекте с такой функцией авторского комментирования, как выражение достоверности. Эту функцию часто выполняют глаголы восприятия в результативно-фактическом перфектном значении. Восприятие выступает как доказательство достоверности некоторого факта, утверждения: (17) Дед Чудодей был очень мудрый, и поговаривали, что он понимает язык птии и зверей и часто в лесу беседует с ними. Правда, никто этого не видел. Но, наверное, не зря его все-таки назвали Чудодеем (В. Нестайко. В стране солнечных зайчиков); (18) Такого я действительно никогда не видел. Они, видимо, очень набожны (В. Пелевин. Затворник и Шестипалый).

Глаголами восприятия с отрицанием не сльшил, не видел фиксируется отсутствие у героя соответствующего опыта. В последующем контексте раскрывается сам процесс осмысления новой ситуации, для выражения которой могут использоваться показатели приблизительности, неопределенности (вводно-модальные слова видимо, наверное). Несмотря на то, что в данных контекстах употреблены разные глаголы (видеть и сльшиать) в сходном значении, они взаимозаменяемы, что позволяет говорить о нейтрализации способа восприятия в таком типе ситуаций.

Важно отметить, что все названные функции могут выполняться одной словоформой. Например, в примерах (3) и (4) ретроспективная композиционная функция совмещена с сопоставительной, конструкция «успел что-то сделать» обычно выражает регресс, ретроспекцию и временную сопоставительность, функция обобщения часто сочетается с ретроспекцией.

В заключение подчеркнем еще раз следующую идею: для различных текстовых функций глагольных словоформ на первый план выходят различные условия реализации перфектного значения. Для композиционных функций перфекта важны его синтаксические свойства: позиция относительно ССЦ, а также валентность, которая тесно связана с лексическим значением глагола.

Выражение перфектными глаголами сюжетно-событийного движения повествования обусловлено прежде всего типом перфекта. Типичный акциональный перфект (глагол совершенного вида в результативно-перфектном значении) способствует продвижению повествования, а типичный качественный перфект (страдательное причастие со связкой) - остановке повествования. Часто первые два типа функций сочетаются у одной словоформы с функцией авторского комментирования.

\section{Литература}

Бондарко А.В. Содержание и типы аспектуальных отношений // Теория функциональной грамматики: Введение. Аспектуальность. Временная локализованность. Таксис. М., 1998. С. 223-278.

Золотова Г.А. Очерк функционального синтаксиса русского языка. М., 1971. C. $113-125$.

Кашкин В.Б. Функциональная типология перфекта. Воронеж, 1991. С. 5-128.

Князев Ю.П. Грамматическая семантика: Русский язык в типологической перспективе. М., 2007. С. 458-502. 
Маслов Ю.С. Избранные труды: Аспектология. Общее языкознание. M., 2004. C. 216-225.

Падучева Е.В. Семантические исследования (Семантика времени и вида в русском языке. Семантика нарратива). М., 1996. С. 52-88.

Прокопович Е.Н. Глагол в предложении. Семантика и стилистика видовременных форм. М., 1982. С. 74-107.

Пупынин Ю.А. Грамматические категории русского глагола в их системнопарадигматических и функциональных связях // Межкатегориальные связи в грамматике. СПб., 1996. С. 22-61.

Тимофеев К.А. К истории форм прошедшего времени русского глагола // Ученые записки Благовещенского государственного педагогического института им. М.И. Калинина. Благовещенск, 1941. Т. 2. С. 35-47.

\section{Список источников}

Пелевин В.О. Generation Р. М., 1999.

Пелевин В.О. Все повести и эссе. М., 2005.

Толстая Т.Н. Река Оккервиль. М., 2005.

Улицкая Л.Е. Рассказы. М., 2009. 